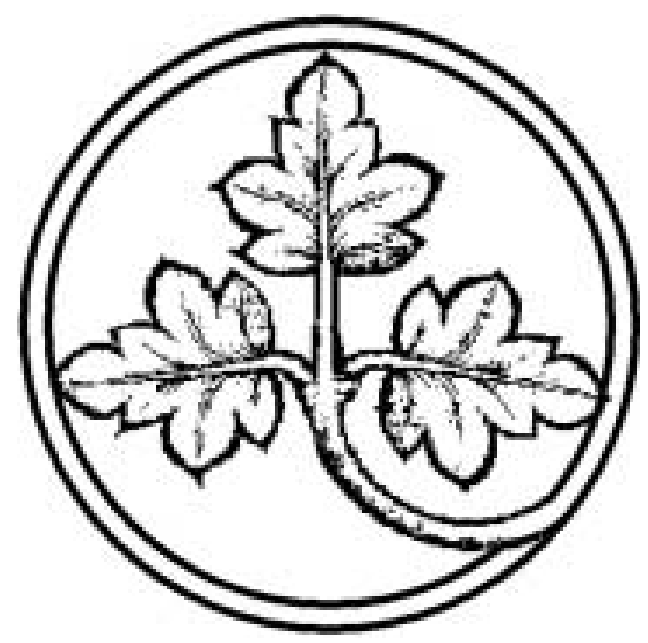

Gemeinschaftsgüter: Recht, Politik und Ökonomie

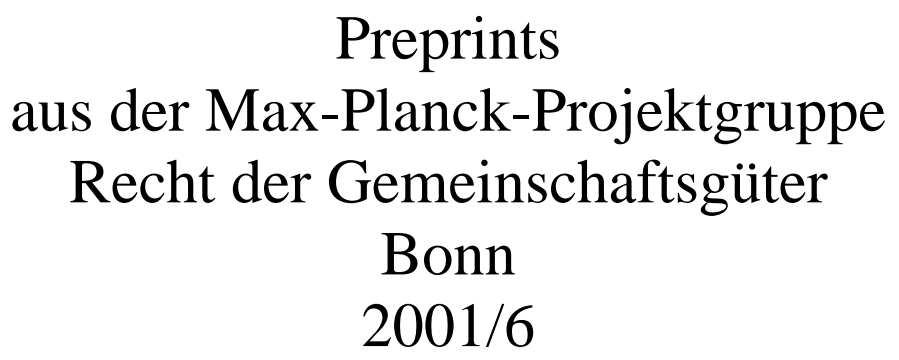

Composite Democratic Legitimation in Europe: the Role of Transparency and Access to Information

Von

Adrienne Héritier 


\section{Composite Democratic Legitimation in Europe: the Role of Transparency and Access to Information}

Adrienne Hénitier

June 2001

Max-Planck-Projektgruppe Recht der Gemeinschaftsgüter, Poppelsdorfer Alle 45, 


\section{Composite Democratic Legitimation in Europe: the Role of Transparency and Access to Information}

\section{Introduction}

The European Union is a composite democracy (Héritier 1999a; Benz 1998; Auel et al 2000; Manin 2000). It is comprised of diverse elements of democratic legitimation: the vertical legitimation through parliamentary representation in the EP; executive representation through delegates of democratically-elected governments in the Council of Ministers; horizontal mutual control among member states; associative and experts' representation (delegation) in policy networks (Benz 1998); and, finally, individual rights based legitimacy. Together these elements paint a variegated picture of the reality of democratic legitimation in Europe. The individual elements have not been developed and linked in a systematic and consistent way; rather, they have emerged from a series of pragmatic decisions, made among the range of limited possibilities allowed for by the unanimity requirements of the intergovernmental conferences or as a result of incremental individual initiatives of the different European decision-making bodies. As a consequence, it does not come as a surprise that some elements are incompatible with each other, both with respect to their primary goals and their modes of operation. The nature, reasons and consequences of this type of incompatibility or compatibility are at the centre of this article. Of particular interest is the question of relationship between the legimatory components of access to information and transparency, on the one hand, and the element of negotiative democracy that is, governance in policy networks, as an ubiquitous mode of governance in Europe, on the other. While transparency and access to information stress the input-oriented goals of democratic legitimation, that is the right to know who makes which decisions when, associative representation and negotiative democracy emphasise the output-oriented goals of democratic legitimation, that is government legitimation through policy performance accommodating the widest possible scope of interests. Both - input- and output oriented legitimation - are important and have to be viewed in their reciprocal relationship.

The argument developed in this article will proceed in the following steps: In the first step the various strands of democratic legitimation are described, and transparency, and access to 
information are situated in the overall context of the elements of democratic legitimation existing in the European Union. In the second step the programme to increase transparency is specified in more detail. In the third step a discussion ensures the compatibility of the relationship between access to information and transparency, on the one hand, and the central components of European democratic legitimation, on the other. ${ }^{1}$ In a fourth step normative conclusions will be drawn with respect to the possible functions that access to information and transparency - bearing the compatibility of the individual components in mind - serve in the context of the composite democracy in Europe.

\section{$2 \quad$ Europe as a composite democracy}

Democratic legitimation in Europe is a patchwork of different strands of democratic legitimation. Firstly, it reflects the republican/representative tradition of rule in which there is a system of popular control over governmental decisions with a government that is responsive to the people by deciding through its representatives, who are chosen in free and secret elections. However, because European elections dominantly respond to national political issues, they "short-circuit the connection between the public and its representatives in the European arena" (Lord 1998:68) Additionally, the European Union is not completely democratic (in the strictest sense) since its popularly-elected parliament has only limited decision-making powers and only limited control over the executive branch, the Commission. The threat to dismiss the Commission as a collegiate body is too drastic an instrument to be practically used. But the power to table motions of censure has proved quite effective in make the Commission sensitive to opinions of the EP (Westlake 1994), the Commission strongly depending on credibility across the Union as a whole (Lord 1998:61). However, the fact that a majority in the EP does not need to support a government and se cure its stability, offers the advantage that - depending on the issue at hand - changing majorities can be formed and the support of the EP must be sought on a case by case basis allowing the Parliament to move freely across the range of the political debate (Lord 1998:65). Members of the EP are mostly policy specialists which at the same time have to be consensus -oriented in the transnational party political context (Lord 1998:85). The EP does serve as a public forum in which

In a later stage of research the propositions developed on the basis of theoretical arguments and arguments for plausibility will be empirically validatedon the basis of expert interviews. 
governmental functions are subjected to a critical judgment (Mill 1972). Plenary debates may be called relatively easily. Members of the Commission and the Council take part in these debates. Parliamentary committees function as important sites of public debate in many policy areas. (Lord 1998:66). In this context public discourse as an important element of democratic legitimation, based precisely on transparency, information and communication come to bear. Here exchange of opinions and arguments opening up possibilities of deliberation. (V. Schmidt, forthcoming).

In sum, the goal of this the most important strand of democratic legitimation is equal representation and the pursuit of the common welfare by generating and controlling a government; the prevalent mode of decision-making is voting in the plenary sessions, in the committees consensual decision-making may be frequent as well.

The second element of intermediate democratic legitimation by executive representation (Benz 1998) or legitimation by delegation is evident in the fat that the most important intergovernmental decision-making body, the Council of Ministers, consists of delegates of the member-state governments who themselves are democratically elected. Hence, there is an indirect democratic legitimation along the vertical axis. However, to the extent, that memberstate government preferences are also formed in the course of Council negotiations, this body may not be adequately authorized through the election of its parts. During bargaining governments may have to or want to change their preferences in order to be able to come to an agreement (Lord 1998: 32). An important aspect of this type of legitimation is that it must be guaranteed that each member state has the same chance to realise its interests, no structural disadvantages for any participant are implied, and the protection of minority interests is guaranteed (Hüglin cit after Benz 1998). This is most easily guaranteed if decisions are made through negotiations, on the basis of individual issues (including package deals and issue linkage), instead of through majority voting on the basis of long-term interest factions concerned with various issues which neglects the interests of the minority, which is outvoted. Bargaining democracy creates input-legitimation since it prevents individual interests from being outvoted and thereby forces actors to take multiple interests into account. No individual party would be willing to support a decision if it would make it worse off than under the status quo conditions. This is reflected in the more equitable outcomes of the bargaining processes. By virtue of precisely this fact, bargaining democracy also constitutes a source of output-legitimation. The underlying process mechanism is consensus-building, attained with the help of compromises, compensation payments and package deals. This is enhanced by a 
context of long-term bargaining arrangements, which characterise many policy areas in the European Union that favour reciprocal action. This tends to produce a balanced profit "sheet" in so far as the actors involved are aware that they will remain together and are therefore willing to forgo short-term benefits in favour of long-term gains and to take the interest of the other actors involved into account, knowing that in the future they in turn may well depend on the support of the others. Under conditions of reciprocity and balanced structural conditions of participation, it may also be possible to initiate a phase of problem-solving-oriented bargaining or deliberative bargaining, in which the possible joint gains might be discerned and extended - before the actors proceed to defensive, and individualistic, profitoriented bargaining (Héritier 1999b). Hence, the goal of executive representation or representation by delegation is to come to policy decisions accommodating all member-state interests or the largest possible number of interests; the prevalent mode of decision-making is through negotiations.

Thirdly, European democracy also reflects elements of accountability, defined as the possibility to control the political power which has been authorized, through mutual horizontal control deriving from the Montesquieuian and Madisonian tradition in a system of separated powers. In the Federalist Papers (1788) Madison develops a system of integrated political powers aimed at ensuring the mutual institutional control of political power. In Madison's theory of the control of factions, he claims that the tyranny of a majority can only be contained by creating a plurality of factions which keep each other under control (Madison 1981 - 1787). This has also been elaborated by the theory of pluralist democracy proposed by Lindblom (1977) and Dahl (1963). Since a "general will" is not easily defined in a complex modern society - owing to a wide distribution of political resources - pluralism and polyarchy prevail, and power is controlled by counter-powers, resulting in a situation in which no single group dominates the policy-making process (Steffani 1973; Grant Jordan 1987). Europe, as a polity whose very diversity is represented by the member states, constitutes a form of checks and balances to political power, based on individual member states (Héritier 1999a; Grande 2000). According to this notion, it is possible to effectively control poliical power through the institutionalisation of counterbalancing national forces. At each step of the European policy process, from the first tentative drafts to the formal decision-making process, the policy proposals of the actors involved are viewed with distrust and circumspection. The participants controlling each other are generally experts and/or decision-makers from the different member states, responding to each other's policy proposals with counterproposals 
backed up by expertise. The mutual distrust offers an enormous potential for control and a chance to hold actors accountable for individual policies; such moves need to be defended in substantive terms. This is the virtuous aspect of the slow pace, and indeed potential deadlock, inherent in the European decisional process. This phenomenon is widespread and permeates virtually the entire fabric of the decision-making process (Héritier 1999a:274). This mutual control also exists between the different formal decision-making bodies, the Commission (as initiator), the Council and the EP in the co-decision process.

The primary goal of this type of democratic legitimation is to provide for accountability; the mode of action applied is control and, indeed, distrust.

Fourthly, there is the aspect of the tradition of associative and expert representation or democracy by negotiation, reflected in the fact that policy-making often takes place in policy networks in which sectoral interests are represented and negotiated among associative and independent experts, delegated by member states; in the course of these negotiations deliberation processes can take place, and compromises are struck. Although these networks do not have formal decision-making power, they play an important role in prestructuring formal decisions (Benz 1998:352; KohlerKoch 1998; Mazey and Richardson 1993, Schmitter 1994). Thus comitology has developed a working style which still pursues national interests; however, it is also geared to finding new solutions to problems which are acceptabe for all concerned (Joerges and Neyer 1998). The Commission promotes this style of decisionmaking by establishing fora to exchange information and share experiences. It seeks to use these committees to prepare and deliberatively structure the decision-making process and to reach a balance between output-rationality, procedural transparency, and fairness with respect to those affected by these decisions (Joerges and Neyer 1998:230). There are numerous indicators of this style of decision-making, geared towards consensus: the numerous consultations between the Commission and member-state associative representatives; the infrequency of strategic coalitions between delegates from different member states; the low rate of disapproval of decisions; the frequent modification of Commission proposals in the meetings; as well as the large number of consensual decisions (Joerges and Neyer 1998:223). The danger of this mode of decision-making is that the represented interests may be biased. If there is not a well-balanced selection of participants, the participants may come to an agreement at the cost of those who are not participating in the negotiations. 
In sum, the primary goal of this strand of negotiative legitimation is outputoriented, and it aims at reaching policy decisions which satisfy as many of the concerned interests as possible; the prevalent mode of decision-making is through deliberation and negotiation.

Fifthly, there is the notion of democracy which guarantees a system of fundamental rights (liberal tradition); it views democracy as providing an extensive body of rights, such as the freedom of speech and assembly, that offer opportunities essential for popular control and for the functioning of the democratic institutions themselves for Europe (Engel 2000). The two elements of democracy under study here belong to that tradition. Transparency and access to information determine who has the right to know who the decision makers are, what procedures they employ, what their areas of interest are, and what the consequences of their decisions are. Protecting other rights (such as property rights, and the right to privacy) serves to restrict political power - to some extent - by removing these rights from the realm of government decisions, or at least to justify the proportionality of such an intervention adequately so that legislatures do not have the power to override or compromise these rights (Dworkin 1991, Kuper 2000:157). These rights are not essential for the functioning of democratic institutions, as such, but are oriented towards legitimation through output (Dahl 1999:20).

In short, the primary goal of this tradition of democratic legitimation is to protect individual rights in order to ensure democracy; the mode in which this is done is through guaranteeing individual rights for information, or for complaint.

Access to information, particularly when it is directed to administrative behaviour, also reflects the tradition of responsive democracy, developed in the 1970s and 80s as a critique of bureaucratic/administrative behaviour, which was judged to be irresponsive to the needs and demands of citizens. The argument was precisely the reverse of the one we are discussing in the European context today when a lack of parliamentarian representation is criticised as the main deficiency of our democracy. In that earlier debate it was claimed that democracy via parliamentary representation during the input phase of policy-making was not sufficient to realise democracy and that during the output phase of policy-making administrative behaviour should also be held accountable and be responsive to the wishes of citizens. A variety of institutions, particularly at the local level, such as citizens' information offices, interest groups or citizens' watchdog bodies, were developed in order to allow citizens and associations to exert influence on administrative behaviour (Héritier 1999a). 
Table 1: goals and decision-making modes of different strands of democratic legitimation

\begin{tabular}{|c|c|c|c|c|c|}
\hline goal & \multicolumn{3}{|c|}{ input } & \multicolumn{2}{|l|}{ output } \\
\hline mode & $\begin{array}{l}\text { equal } \\
\text { represent. }\end{array}$ & $\begin{array}{l}\text { minority } \\
\text { protection }\end{array}$ & $\begin{array}{l}\text { control/ } \\
\text { accountability }\end{array}$ & $\begin{array}{l}\text { problem-solving } \\
\text { pareto-optimal } \\
\text { or Kaldor } \\
\text { criterium }\end{array}$ & $\begin{array}{l}\text { indiv.- / } \\
\text { interest }\end{array}$ \\
\hline $\begin{array}{l}\text { voting / } \\
\text { majority }\end{array}$ & $\begin{array}{l}\text { republ. tradit. } \\
\text { (EP) }\end{array}$ & & EP vertical & & \\
\hline negotiation & & $\begin{array}{l}\text { executive } \\
\text { representation } \\
\text { (Council) }\end{array}$ & $\begin{array}{l}\text { executive } \\
\text { representation } \\
\text { horizontal }\end{array}$ & $\begin{array}{l}\text { associative/expert } \\
\text { representation } \\
\text { (SEC, policy } \\
\text { networks) }\end{array}$ & \\
\hline deliberation & & & & $\begin{array}{l}\text { assoc./exp. } \\
\text { representation } \\
\text { (policy networks) }\end{array}$ & \\
\hline $\begin{array}{l}\text { individual } \\
\text { demand/ } \\
\text { complaint }\end{array}$ & & access to info & $\begin{array}{l}\text { transparency } \\
\text { progr. }\end{array}$ & & $\begin{array}{l}\text { access to } \\
\text { info }\end{array}$ \\
\hline $\begin{array}{l}\text { vertical } \\
\text { control }\end{array}$ & access to info & & & & \\
\hline $\begin{array}{l}\text { mutual } \\
\text { horizontal } \\
\text { control }\end{array}$ & & & $\begin{array}{l}\text { diversity } \\
\text { of actors, } \\
\text { bodies }\end{array}$ & $\begin{array}{l}\text { executive } \\
\text { representation } \\
\text { Council }\end{array}$ & \\
\hline
\end{tabular}

All the above-mentioned elements of democratic legitimation co-exist in European policymaking and are linked such that various elements are necessary to produce a decision. To that extent, there is an enhanced potential that certain elements will be either mutually supportive or incompatible.

How does the European programme to increase transparency fit into the context of this composite European democratic legitimation? Before examining this, various questions need to be addressed: what does the programme intend to achieve, what does it consist of and why was it introduced? 
The attempt to introduce open government and more transparency into European policy making itself consists of several separate debates - and indeed measures - which basically centre around two conceptions: access and communication (Grønbech-Jensen 1998). Access implies two possibilities: active access, on the one hand, i.e. the possibility to carry information, and even demands, into a political or administrative decision-making body, with or without the explicit right of being heard and that the decision-making body reacts formally the concern at issue ; and passive access, on the other i.e. the possibility to gain information about on-going decision-making processes and the persons involved in a decision-making body. These possibilities exist for organised interest groups as well as for individual citizens. The access organised by European decision-making bodies is somewhat different in terms of the collective in-take of information, for instance, through consultation processes and public hearings. Communication, by contrast, involves information that is offered from the "topdown" by decision makers in a policy-making body; this information, is offered in a processed form through the decision-making structures, of the respective decision-making body. It may take the form of information brochures, information on the internet, for instance, or information talks.

Table 2: Elements of the transparency programme

\begin{tabular}{|l|l|}
\hline $\begin{array}{l}\text { Communication } \\
\text { Political body } \\
\text { down }\end{array}$ & $\begin{array}{l}\text { Access } \\
\text { Who: Citizens } \\
\text { Organ. interests }\end{array}$ \\
\hline $\begin{array}{l}\text { info brochures } \\
\text { info talks } \\
\text { internet }\end{array}$ & $\begin{array}{l}\text { access } \quad \text { - info: passive } \\
\text { - info: active influence } \\
\text { access to - administr. }\end{array}$ \\
\hline & $\begin{array}{l}\text { Organized "in-take" of information } \\
\text { - consultation } \\
\text { - hearing }\end{array}$ \\
\hline
\end{tabular}

The debate about transparency and access to information came about because of the lack of transparency and openness in the complicated European decision-making processes, which has tended to intensify problems of control and accountability. Because of the opacity of the 
decision-making processes of the Community bureaucracy and its innumerable informal committees as well as the Council meetings and opaque policy networks, an attempt was made to secure a right to information in these areas (Grande 2000:126). "The Council is a process of government by permanent negotiation $n$ which the legislative process is difficult to disentangle from the legitimate rights of actors to protect the secrecy of their bargaining hands" (Hayes -Renshaw and Wallace 1997, in Lord 1998:87)

To some extent, the origin of the programme to increase transparency can also be traced to the lack of the success of more ambitious institutional reforms (Héritier 1999b) Due to unanimity requirements in the intergovernmental-conference arena and the often resulting deadlock, it is all but impossible to bring about significant formal institutional reforms to enhance democracy in Europe. Therefore, decision-makers tend to settle for more modest incremental reforms to which everyone can agree. Yet, these seemingly modest reforms may inadvertently turn out to be real instruments of change, although - or rather because - they are not very conspicuous. By constantly pragmatically reshaping inter-institutional relations and their procedural rules, such as between the Commission and the EP, with the goal of increasing the access to information - of the EP to, say, comitology (Lodge 1994) - inconspicuous, but important changes in the de facto inter-institutional decision-making have been made.

In the emergent debate about the deficiency of European democracy, the Commission was blamed for its "alleged arrogant detachment from the public in particular" (Lodge 1994:343), for policy-making behind "closed doors," technocratic decision -making in expert groups, and comitology. The critique was sharpened when the legislative functions were expanded under the Maastricht Treaty. Hence in its final declaration, the Lisbon summit - briefly after the Danish no vote to the Treaty of the European Union - committed member states to more transparency (Peterson 1995: 474). With the accession of Sweden and Finland in 1995- with their traditions of transparent government at home - the debate on opening up the European decision-making process gained momentum (Peterson 1995; Grønbech-Jensen 1998:190). Thus Delors - in co-operation with the EP - announced a crusade for democracy in order to render Community action more transparent, and he began working on a communication policy (Delors, Strasbourg, 10/2/1993, cit. after Lodge 1994: 343; Peterson 1995:477). Improved access to information was seen as a means of bringing "the public closer to the EC's institutions and a way of stimulating a more informed and involved debate on European policy" (Lodge 1994:350). 
Depending on the institution at stake, access and communication have different implications. In the Commission the debate focuses on two aspects: First, it focuses on how to strengthen organised interests' access to and their participation in the policy formulation process. It thus developed a time-table for the annual working plan, which would allow organised interests better access during the preparatory phase of the Community policy (Lord 1998:87). Moreover, new procedures for consultation with affected interest groups (and individuals) were formulated (Gronbech-Jensen1998:191), and a list of the groups and lobbyists having ties with the Commission was put together (Peterson 1995; Grønbech-Jensen 1998:187) Second, the Commission encouraged the administrations of member states to make implementation information accessible to citizens (Bugdahn 2000; Héritier 1999a). While the Commission accepted the principle of "transparency through access" expecting members of the public to approach the Commission for information, the Council emphasises "transparency through communi cation " seeking to explain and justify outcomes (Grønbech Jensen 1998; Lord 1998)

With respect to the Council of Ministers, where decision-making has traditionally been secretive, the debate is about how to increase democratic control by granting national parliaments and the press access to the decision-making process without losing efficiency (Grønbech-Jensen 1998:187). The Council, whose deliberative meetings are closed to the public (meetings of the Council for legislative work can only be made public through unanimous decisions Grønbech-Jensen 1998:192) and whose documents are largely inaccessible to third parties, is particularly being challenged. Until recently, unless the Council decided otherwise, negotiations in the Council were covered by a rule of extensive confidentiality, and public access to Council documents (minutes of meetings, including explanatory statements made at the moment decisions are adopted, preparatory documents, etc.) could be denied according to this rule of confidentiality. Under the Amsterdam Treaty the secrecy rules have been somewhat loosened. That treaty includes a general principle of openness. Art 207 states that when the Council acts in its legislative capacity the results of votes, and explanations of votes, as well as statements in the minutes shall be made public (Guggenbühl 1998:18) A new Art. 255, on the access to documents, was introduced. But neither the famous Guardian case nor the WWF 2) case have made it completely clear where the right balance between the need for deliberations and the citizens' interests in accessing Council documents lies (Guggenbühl 1998:13). 
The declarations of the Amsterdam Treaty hold for the EP as well; that is, it is subject to the right of access within the limits set against the bakground of public and private interest.

After long discussions it attempts to make the relations between individual members of the EP and interest groups transparent by registering contacts and economic transactions between its members and lobbyists. The Charter of Fundamental Rights of the European Union establishes a right of access to the documents of the EP, Council and the Commission.

The new rules formulated in the regulation on the access to sensitive internal papers have been contested between the Commission, the EP and the Council. The Commission wants to see a rather strict definition of a document, excluding informal messages, discussion texts and papers setting out internal department's opinions, while the EP argues that documents given to the EU's institutions by third parties should be made public, with exceptions clearly defined. The EP spokesman also requested that access should not only imply access to policy documents, but also to information on decision processes in European institutions. (Taylor 2000:7) . The Council scaled down the scope of the public register of classified documents on Common Security and Defense Policy. The report of the EP rapporteur Cashman retains six exceptions for access (defence, public order, montary stability, international relations, the protection of individuals private lives and professional confidentiality) while the Council proposed 12. The Swedish Presidency in principal in favour of transparency is expected to support the EP's endeavours (Agence Europe 2001, January III 13, 14)

However, since there are strong pressures from Sweden to strengthen intergovernmentalism, the Presidency cannot full-heartedly support the transparency claims of the EP which is viewed as a body representing supranationalist tendencies

Within the context of the different components of democratic legitimation described above e.g. vertical legitimation through parliamentarian representation, indirect democratic legitimation through executive representation, mutual horizontal control, associative/expert representation, and individual-rights legitimation - transparency and access to information only play a subsidiary role. In other words, transparency and access to information do not constitute a form of democratic legitimation in their own right; because they do not entail an element of decision-making; however, they are a crucial element of some modes of democratic legitimation without which the latter cannot function satisfactorily. In some cases, however, the thrust of the transparency programme may conflict with the goals pursued by a specific strand of democratic legitimation. 


\section{Transparency and the main forms of democratic legitimation}

What - more specifically - are the links between the five central strands of democratic legitimation and transparency? To what extent is the relationship between the goals and modes of each type of democratic legitimation supportive of or in contradiction with increased transparency?

In the context of the main form of representative/republican democratic legitimation, transparency and access to information play a straightforward supportive role. They function as a prerequisite for exercising popular control over government activities (with this popular control being instituted as a fundamental right); they also function as a prerequisite for the attempts of organised interests to influence parliamentarian decisions. If these attempts are not structurally biased in favour of only few powerful groups, this pluralist notion of a democracy enhancing quality of interest groups' access to political decisionmakers depends on some notion of the agenda and decision-making structures of the political body addressed. In order to enhance the elected representatives' accountability to the electorate, citizens need information about their representatives' decision -making and the outcomes of their decisions. When - along with the Commission and the Council - the EP, as a policy-making parliament, defines the political agenda, when it mediates interests, and participates in European legislation, then both the citizens' input and the input of organised interests who aim to purvey their views, support the members of the EP in fulfilling this role. Furthermore, at a procedural level the EP is also obligated to discbse which organised groups and individuals not merely want to be informed, but actively seek to influence the decision-making process; this marks an attempt to avoid a structural bias in the access process which might selectively favour powerful organised interests. Hence, the programme for increasing transparency has an unmitigated, positively supportive impact on this main strand of democratic legitimation.

In the case of executive representation, which is primarily of interest in the Council of Ministers, the relationship is more complicated. Since the Council acts as an intergovernmental body, consisting of delegates of democratically-elected governments, it obeys different decision-making rules. Being composed of diverse members and being subject to the needs of minority protection, it cannot simply impose majority rule, but has to rely on negotiations as it tries to accommodate the diverse interests of all the concerned actors, and 
reach compromises (Curtin 1995:78). As the primary locus of executive epresentation, the Council is thus faced with a trade-off between democratic legitimation and efficacy, efficacy defined as the capability to adopt decisions with the appropriate speed, to generate the degree of acceptability necessary for a consensus, and to implement them with positive results (Piris 1994:454/55). To achieve this, in their decisionmaking the Council and the bodies of the Committee of Permanent Representatives typically engage in painstaking negotiations, shrouded in secrecy, "starting from Commission proposals and carried forward by a succession of Presidency compromises, seeking to accommodate delegations problems until the necessary majority is found" (Curtin 1995:85). If the Council were to deliberate in public, progress would either be blocked "because delegations would be forced to take an immovable position, or the public proceedings would be theatre, with the real business being done by officials behind closed doors" (Curtin 1995:85). The individual citizen or interest organisation cannot be expected to have an interest in a balanced policy result, accommodating all interests concerned. "...There is an obvious danger that an attempt to open the final legislative stages to public purview will only force the real political bargaining bhind the next set of closed doors" (Lord 1998:88). Interestingly, business has been shifted from sectoral councils to the European Council whose decisions are less likely to be criticized by national parliaments in order not to embarrass their heads of government (Lord 1998:88).

The same argument basically holds for the negotiations in the Commission working groups and comitology (associative or expert representation); only here the democratic legitimation problem is compounded because the members of thes e bodies are experts delegated by member states, or representatives of associations, neither of which have a democratic mandate.

The role of the programme to increase the transparency of the main forms of democratic legitimation becomes more complicated when the parliamentarian and executive representation are linked, which is often the case European policy-making. Thus, the Council needs the support of the EP in those areas in which the principle of co-decision applies. Comitology is a case in point: it requires the co-management of the Council and the Commission, and recently, the EP, due to the EP's co-legislation with the Council. The question has been raised regarding the degree of involvement of the Parliament. Here the Parliament quickly suffers from a lack of information of the complex on-going negotiation details, which are not easily compensated for (Benz 1998:355). The procedural agreement 
found is that the Commission and the Council are to send proposed implementation acts to the appropriate committee of the EP and then take its comments into account. The Council shall adopt the act only after informing the EP, waiting for a reasonable time, and taking due account of the EP's point -of-view. However, the Council has not been willing to let the $\mathbf{P}$ participate in the committee meetings (Guggenbühl 1998:35).

Recently a most interesting development has taken place between the Council and the EP which fundamentally influences the relationship between these two bodies and has also repercussions on the transparency programme. Since the new co-decision practice of May 1999 the Council and EP have developed a pre-conciliation procedure to speed up the legislative decision-making process. "The change has been enormous. It is not written on paper. It is hard to see. It is carrying on. There are no rules" (Interview EP Shackleton, March 2001). The reasons for the change have been of a practical nature: widened codecision making causing a higher need for conciliation has on the Council side, in particular for Coreper 1, brought an increased volume of work. Conciliation is costly in terms of time and human resources. Coreper 1 - dealing with most issues of co-decision and therefore conciliation have to deal with everything while its correspondent on the EP side, the particular delegation of the EP, changes with the issue at hand. As a consequence the Council realized that it had to change the mode in which it operates and started to engage with the EP at a much earlier stage of the procedure and with more dense contacts. The aim is to look for an agreement with the EP so that you don't need conciliation. Accordingly, the Council have expanded their secretariat that deals with co-decision so that the fonctionnaires deal with the issue right from the first reading of the EP in order to find agreement earlier or to come close to an agreement to make conciliation easy; to reach conciliation in little trilogue meetings and to confirm the agreements then quickly as "A-points" (in the Council language!) without discussion (Interview EP, March 2001) In these numerous informal meetings between the Council's service traitant and the responsible EP committee there is an early mutual revealing of preferences - (Interview EP March 2001), making a second reading in the EP unnecessary. Thus, the unbundling directive of local loop, the directive on electronic material, and electronic commerce all went from draft legislation to actual law in a record speed. Thus, the number of conciliation procedures in relative terms - against the background of an increased number of co-decision areas - has gone down (Amélioration de l'efficacité de la procedure de codécision 2001). 
The implications of these on-going informal changes for democratic legitimation in general and transparency in particular are mixed. On the one hand, legislative output can be produced faster and more smoothly. On the other hand, there is less openness for the following reasons. The committee committee process as such would be open to the public. Thus, in such a "fast track procedure", for instance, the unbundling of local loops, the committee part is open to access of the public. Also representatives of the different political groups in the EP were nominated to shadow the head of committee. They would go to the ch airperson and say "we like this, we don't like that", the latter functioning as a repository for all different views. His pre-negotiations with the Council are known because he has to report back to committee and to inform the rapporteur (Interview EP Shackleton, March 2001). However, many preconciliation negotiations between the Council and the EP are removed from the public (interview EP Shackleton, March 2001) because the Council prefers to negotiate with individuals (chairperson, the rapporteur), instead of the entire committee. So the committees are in the danger of becoming "chambres d'enregistrements" of agreements negotiated elsewhere. "We are drawn into the way of working of the Council... There is a danger for us becoming the $16^{\text {th }}$ member state, just another party in the negotiations of the $1^{\text {st }}$ reading." (Interview EP Shackleton, March 2001). Considering that one important value of the EP lies in its open discussions and the fact to have time for open discussions, this development seems problematic. For the earlier an agreement is found, the more you reduce input possibilities for civil society and lobby groups. As a remedy, it has been suggested that the committee should define a mandate to negotiate with the Council and then come back to the committee and report (Interview EP Shackleton, March 2001).

Another option is that the Council should go to committee to present the common position and to negotiate with the EP before its second reading and not talk just to the rapporteur: “ The very act would change the nature of the political process" (Interview EP March 2001). But the Council is hesitant to do this- although its rules would permit it - and argues that this does not correspond to its existing practice; that they do not have the time and that it would break the solidarity in the Council. "They do not want to come, partly because it is a public meeting, whereas a meeting with the rapporteur is a private meeting, nobody will report it later. Partly it is out of solidarity with the Council. The are not willing to say 'We are confident to get a 'qualified majority provided that X,Y, Z'." (Interview EP Shakleton, March 2001) It would give the EP, and indeed everybody an opportunity to look into the Council. Instead of the committee, "the Council would prefer to have more little trilogue meetings with 
members of the political groups, a little representative sample of the committee put in a little room, which of course would not be open" (Interview EP Shackleton, March 2001).

With respect to output legitimation it has however to be borne in mind that executive representation trough the Council may be rendered more difficult if systematically linked to parliamentarian representation: the efficiency of bargaining may be jeopardised because party competition comes to bear in the parliamentarian arena and parliamentary cleavages often cross-cut cleavages of interest-groups in specific thematic areas. As a result, complex negotiation compromises may become unravelled once again (Benz 1998:355). However, it has been pointed that the EP itself struggles with the tension between "traditional (left-right cleavages"- conflicts and policy-specific conflicts which are not linked to the former (Lord 1998). Hence the openness for non-traditional cleavages may be more pronounced that assumed.

In the context of horizontal mutual control, the legitimating power resting in the control that one member state exerts over others is demonstrated when that state questions the actions of other member states in the decision-making bodies, asking for justifications, and thereby increasing the individual member states' accountability for their actions. The citizens' information queries and the informational input which organised interests contribute to the delegates/experts of one member state may enhance the information pool of the latter and facilitate their challenge of another member state's position. Hence the relationship between horizontal control and transparency can be considered to be a positive one.

Finally, the notion of democratic legitimation based on individual rights is very closely related with the programme to increase transparency. Access to information and transparency touch upon individual rights: the amount of information available and the degree of transparency entail previous decisions about who has the right to know who is making decisions, or how they are being made, what they are being made about and what the results are (or if you will, about who has the right to know who decides how about what and with what outcome); they also entail a more active component, namely that of actively seeking to influence the decision-making process with a certain information-input. However, 
transparency and access to information may be limited by supporting the opposing rights of those who want to see certain data protected. ${ }^{2}$

Table 3: Transparency Programme and different strands of democratic legitimation

\begin{tabular}{|l|c|c|c|}
\hline \multicolumn{1}{|c|}{ Transparency } & Communication & Access \\
$\begin{array}{l}\text { Strand of } \\
\text { democratic } \\
\text { legitimation }\end{array}$ & & & \\
\hline repres./republ. & + & + & + \\
\hline executive representation & - & - & - \\
\hline mutual horizontal control & + & + & - \\
\hline associat./expert representation & - & - & \\
\hline individual rights legitimation & + & & \\
\hline
\end{tabular}

\section{Conclusion}

If democracy is to effectively transmit citizens' interests into European governance, to contain the power of individual bodies and actors by holding them mutually accountable for their decisions as well accountable to citizens, and to provide for effective and acceptable problem solutions, how then does transparency contribute to these aims in the overall context of Europe's composite democracy?

It is quite useful to place transparency in the context of the policy-making cycle (for a similar argument also see Grønbech-Jensen 1998) and to consider its de facto and potential role in the different policy-making stages, those stages being, problem definition, agendasetting, policy preparation, policy formulation, policy implementation and evaluation. To be true, these stages are not strictly separated from each other, rather they overlap to some extent. However, as a main tendency the role of transparency and access to information may be defined for prevailing decision-making types in different (sub-) phases.

2 By establishing a link to the European Ombudsman, these individual rights may be strengthened, but only to a limited degree since the Ombudsman does not have a greater right to access for his investigation than the complainant (Lodge 1994). Furthermore, the European Court of Justice has not recognised the right to access information as a fundamental right (BEUC v. Commission C-170/89). 
During problem definition, it is clearly an advantage for the policymaking process, both with a view to improving input and with a view to increasing the quality of decision output, if there is extensive informational input from citizens and organised interests. It serves to widen the scope of problems perceived by decision makers (see also Benz 1998:359). These views may be presented informally by individuals or in an organised framework such as during a formal consultation process or a public hearing. The modes of organising individual or collective access to information in this phase could be improved in many respects. The biggest problem is that there is a lack of balance regarding the extent to which citizens and organised interest groups profit from access. It is mostly the groups which are already aware of the EU - the 4500 lobbies, 650 consultancy firms and lawyers' offices, and the European correspondents of major newspapers - that take advantage of the possibilities for access in this phase (Guggenbühl 1998:23). An active policy of communication and information can, to a certain extent, compensate for the lop-sidedness in the exploitation of the existing access. ${ }^{3}$

In the phase where specific issues among the myriad of possible issues are chosen for the agenda of the European decision-making bodies, access is narrowed down drastically. It is a very limited circle of actors, in the Commission, the Council and its presidency as well as the EP, who decide in which order which issues are dealt with. Wide-ranging possibilities for popular or associative input in this context would very quickly overload the decision-making capacity of the pertinent bodies. In view of the elitist nature of the agenda setting, it is all the more important that the rules for control and accountability come to bear at the horizontal level, where there is mutual control among actors and bodies, and - once the legislative agenda is enacted - at the vertical level, between the electorate and the responsible policy makers. Here transparency plays an indirect role in that - as described above - it can clearly improve the capacity of the individual actors of the involved bodies to control the actors in another body.

In the phase of policy preparation where policy proposals on specific issues are being drafted, two phases have to be distinguished: a phase which is wide open for informational input, when ideas are collected on how to deal with the problem at hand. Public hearings and formal consultations, and the use of Commission Green and White Papers serve this purpose (Lodge

3 Or the information on the acquis communautaire should be made available as thematic information, in small guides, e.g. on social security for migrant workers. This task should æe performed by a single institution. The Commission would need additional personnel for this (Guggenbühl 1998:23). 
1994:349). The second phase is one of deliberation and bargaining, which, by contrast, is insulated. Here concrete solutions are hammered out in the course of deliberations that aim to realise possibilities for joint gains, despite existing conflicts; in this, complicated negotiations are carried out and compromises formed. Being wide open would jeopardise the possibilities for coming to complicated negotiation compromises (Curtin 1995) since - in order to satisfy their clientele - the individual actors would have to be intransigent in their demands (see also Abromeit/Schmidt 1998:312).

In the actual phase of formal decision-making, however, increasing transparency is crucial. Citizens can only hold the Community legislators accountable if decisions are made public, and if it is possible to identify the decision-makers (Benz 1998:358). Council decisions should be published in full, including the attached declarations, together with the minutes of the legislative sessions and statements of the votes given (Grønbech-Jensen 1998:196). As we have seen, the Amsterdam Treaty has taken important steps in this direction.

Regarding the transparency of implementation and administration, extensive public access to official documents, and files and registers as employed in the Scandinavian policy process, help hold the administrative decision-makers responsible (Windhoff-Héritier 1987) and could also serve to bridge the gap between Brussels and European citizens (Héritier 1999a). Citizens and organisations may not just receive policy information - as access to information in European environmental policy requires (Bugdahn 2000) - they may also play a more active role when, for instance, they are consulted by administrative actors on how to implement a European policy (such as in regional policy) or - one step further - when their active cooperation is required in implementing European policies. Finally, in evaluation transparency should be wide in scope and offer information about programme performance, its success or failure.

Table 4: Transparency in different policymaking stages

\begin{tabular}{|c|c|}
\hline Problem definition & + \\
\hline Agenda setting & - \\
\hline Policy preparation & - \\
formulation & + \\
\hline Implementation & + \\
\hline Evaluation & + \\
\hline
\end{tabular}


In conclusion, if used in flexible, differentiated, and balanced ways, which take both the input and output requirements of democr atic legitimation in Europe into account, the programme to increase transparency can support the main strands of democratic legitimation in Europe without simply creating new veto points (Auel et al 2000). However, although it is a constitutive and important element of different modes and practical contexts of democratic legitimation - by itself it is not sufficient and, at best, only play a supportive role. By no means can it be used as an attempt to side-step a European debate on inter-institutional reform (Lodge 1994:345) to enhance democratic legitimation.

\section{References}

Abromeit, H. and T. Schmidt (1998) 'Grenzprobleme der Demokratie: konzeptionelle Überlegungen', in B. Kohler-Koch (ed.), PVS Sonderheft 29, pp.293-320.

Auel, K., Benz, A. and Esslinger, T. (2000) 'Democratic Governance in the EU. The Case of Regional Policy', in Benz, Arthur, Roland Czada, and Georg Simonis (eds.) Fernuniversität Hagen, Polisno. 48/2000.

L'Amélioration de l'efficacité de la procédure de codécision (2001) Rapport de la Précidence et du Secrétariat Général du Conseil au Conseil Européen, Bruxelles 2001.

Benz, A. (1998) 'Politikverflechtung ohne Politikverflechtungsfalle- Koordination und Strukturdynamik im europäischen Mehrebenensystem', Politische Vierteljahresschrift 39(3), pp. 558-589.

Bugdahn, S. (2000) 'Freedom of Access to Information on the Environment: The EU Directive and its Implementation', Thesis Manuscript, European University Institute, Florence.

Curtin, D. (1995) 'Betwixt and Between: Democracy and Transparency in the Governance of the European Union', in The Treaty on the European Union, Suggestions for Revision, Conference, The Hague, pp.75-104.

Dahl, R. A. (1963) Who Governs? Democracy and Power in an American City. New Haven: Yale University Press.

Dahl, R. A. (1999) On Democracy. New Haven: Yale University Press.

Dworkin, R. (1991)Taking Rights Seriously (6 ${ }^{\text {th }}$ edition), London: Duckworth.

Engel, D. (2000) 'The European Charter of Fundamental Rights. A Changed Political Opportunity Structure and its Dogmatic Consequences'. Manuscript Max Planck Project Group: Law, Politics and Economics, Bonn. 
Grande, E. (2000) 'Post-National Democracy in Europe' in M. Greven, and L. Pauly (eds.) Democracy beyond the State? The European Dilemma and the Emerging Global Order. Boulder: Rowman \& Littlefield Publishers Inc, pp. 115138.

Grant Jordan, A. (1987) 'Pluralism' in V. Bogdanor (ed.), The Blackwell Encyclopaedia of Political Institutions. Oxford: Blackwell.

Grønbech-Jensen, C. (1998) 'The Scandinavian Tradition of Open Government and the European Union: Problems of Compatibility?', Journal of European Public Policy 5(1), pp. 185-199.

Guggenbühl, A. (1998) 'A Miracle Formula or an Old Powder in a New Packaging? Transparency and Openness after Amsterdam', in V. Deckmyn, I. Thomson (eds.) Openness and Transparency in the European Union, European Institute of Public Administration, Maastricht, pp. 9-38.

Hayes-Renshaw, F. and Wallace, H. (1997) The Council of Ministers, London: Macmillan Press Ltd.

Héritier, A. (1999a) 'Elements of democratic legitimation in Europe: an alternative perspective', Journal of European Public Policy 6(2), pp. 269-282.

Héritier, A. (1999b) Policy-Making and Diversity in Europe: Escape from Deadlock. Cambridge: Cambridge University Press

Joerges, Ch. and J. Neyer (1998) 'Von intergouvernementalem Verhandeln zur deliberativen Politik: Gründe und Chancen für eine Konstitutionalisierung der europäischen Komitologie', in B. Kohler-Koch (ed.) PVS Sonderheft 29, pp. 207-233.

Kohler-Koch, B. (1998) 'Effizienz und Demokratie: Probleme des Regierens in entgrenzten Räumen', in B. Kohler-Koch (ed.) PVS Sonderheft 29, pp. 11-25.

Kuper, R. (2000) 'Democratization: a constitutionalizing process' in C. Hoskyns and M. Newman (eds.) Democratizing the European Union. Issues for the twenty-first century. Manchester: Manchester University Press, pp. 15675.

Lindblom, C. (1977) Politics and Markets: the world's political-economic systems. New York: Basic Books.

Lodge, J. (1994) 'Transparency and Democratic Legitimacy', Journal of Common Market Studies 32(3), pp. 343-368.

Lord, C.(1998) Democracy in the European Union, Sheffield: Sheffield Acadamic Press.

Manin, B. (2000) Oral statement at the colloquium 'LIntégration européenne: entre émergence institutionelle et recomposition de lÉtat', Paris Mai 2000.

Mazey, S. and J. Richardson (1993) 'Conclusion: a European policy style?' in S. Mazey, and J. Richardson (eds.) Lobbying in the European Community. Oxford: Oxford University Press. 
Mill, J.S. 1972Utilitarianism: On Liberty and Representative Government. London: Dent.

Peterson, J. (1995) 'Playing the Transparency Game: Consultation and Policy-Making in the European Commission', Public Administration 73, pp.473-492.

Piris, J.-C. (1994) 'After Maastricht, are the Community Institutions more Efficacious, more Democratic and more Transparent ?' European Law Review (19).

Schmidt, V. 'Does Discourse Matter in the Politics of Welfare State Adjustment' Comparative Political Studies (forthcoming).

Schmitter, P. (1994) 'Interests, Associations and Intermediations in a Reformed Post-Liberal Democracy.' Politische Vierteljahresschrift, 35, Sonderheft 25, „Staat und Verbaende” pp. 160-74.

Schmitter, P. (2000) How to Democratise the European Union - and Why Bother? Oxford: Rowman \& Littlefield Publishers Inc.

Steffani, W. (1973) 'Einleitung', in F. Nuscheler and W. Steffani (eds.), Pluralism: Konzeptionen und Kontroversen, Munich: R. Piper \& Co. Verlag.

Taylor, Simon, 'Row over access to EU documents hots up', in European Voice, 29 June - 5 July, 2000, p. 7

Westlake, M. (1994) The Commission and the Parliament: Partners and Rivals in the European Policy-Making Process, London: Butterworth.

Windhoff-Héritier, A. (1987)Policy-Analyse. Eine Einführung Campus Verlag. 